\title{
Oncogenic Abl and Src tyrosine kinases elicit the ubiquitin-dependent degradation of target proteins through a Ras-independent pathway
}

\author{
Zonghan Dai, ${ }^{1}$ Robert C. Quackenbush, ${ }^{2}$ Kevin D. Courtney, ${ }^{1}$ Matthew Grove, ${ }^{1}$ David Cortez, ${ }^{1}$ \\ Gary W. Reuther, ${ }^{1}$ and Ann Marie Pendergast ${ }^{1,3}$
}

${ }^{1}$ Department of Pharmacology and Cancer Biology and Division of Hematology-Oncology, ${ }^{2}$ Department of M edicine, Duke University Medical Center, Durham, N orth Carolina 27710 USA

\begin{abstract}
Oncogenic forms of the Abl and Src tyrosine kinases trigger the destruction of the Abi proteins, a family of Abl-interacting proteins that antagonize the oncogenic potential of Abl after overexpression in fibroblasts. The destruction of the Abi proteins requires tyrosine kinase activity and is dependent on the ubiquitin-proteasome pathway. We show that degradation of the Abi proteins occurs through a Ras-independent pathway.

Significantly, expression of the Abi proteins is lost in cell lines and bone marrow cells isolated from patients with aggressive Bcr-Abl-positive leukemias. These findings suggest that loss of Abi proteins may be a component in the progression of Bcr-Abl-positive leukemias and identify a novel pathway linking activated nonreceptor protein tyrosine kinases to the destruction of specific target proteins through the ubiquitinproteasome pathway.
\end{abstract}

[Key Words: Abi; Bcr-Abl; v-Src; ubiquitin-dependent proteolysis; $\mathrm{Ph}^{1}$-positive leukemia]

Received February 25, 1998; revised version accepted M arch 24, 1998.

Ubiquitin-dependent proteolysis is a critical component of diverse biological processes including cell cycle progression, the immune response, embryonic development, protein transport, and apoptosis (for review, see Deshai es 1995; Hochstrasser 1995; King et al. 1996; Varshavsky 1997). Here we show that ubiquitin-dependent proteolysis may also play a role in oncogenesis by activated nonreceptor tyrosine kinases.

Oncogenic forms of the Abl tyrosine kinase are linked to the development of human, murine, and feline leukemias (Bergold et al. 1987; Rosenberg and Witte 1988; Laneuville 1995; Gotoh and Broxmeyer 1997). Activation of cellular Abl (cAbl) oncogenic potential may occur as a consequence of chromosomal translocation events that generate chimeric fusion proteins such as Bcr-Abl and Tel-Abl (Gotoh and Broxmeyer 1997). The Bcr-Abl tyrosine kinases are produced by a reciprocal $\mathrm{t}(9 ; 22)(\mathrm{q} 34 ; \mathrm{q} 11)$ chromosomal translocation that gives rise to the Philadel phia chromosome $\left(\mathrm{Ph}^{1}\right)$. The translocation fuses varying amounts of the Bcr gene on chromosome 22 with sequences upstream of the second exon of the c-A bl gene on chromosome 9. Three different BcrAbl fusion proteins may be produced. The $210-k D$ form of Bcr-A bl (p210) is the causative agent of $>95 \%$ of hu-

${ }^{3}$ Corresponding author.

E-MAIL pende014@mc.duke.edu; FAX (919) 681-7148. man chronic myelogenous leukemia (CML) cases (Clarkson et al. 1997; Gotoh and Broxmeyer 1997). The 185-kD Bcr-Abl protein (p185) is associated with a subset of acute lymphocytic leukemia (ALL) (Kurzrock et al. 1987). Recently, a rare 230-kD Bcr-Abl protein (p230) has been detected in patients with chronic neutrophilic leukemia (CN L) (Wada et al. 1995; Melo 1996). The p185 and p210 Bcr-Abl proteins have been shown to elicit ALL- and CML-like syndromes in mice, respectively, and to transform fibroblasts and hematopoietic cells in culture (Daley et al. 1990; Heisterkamp et al. 1990). Several mechanisms have been proposed to explain how Bcr-A bl transforms cells. Among these are increased resistance to apoptosis, enhanced proliferative capacity, defective adhesion, and increased motility of the BcrAbl-expressing cells (Clarkson et al. 1997; Cortez et al. 1997; Gotoh and Broxmeyer 1997; Sal gi a et al. 1997). The biological effects of Bcr-A bl require the constitutive tyrosine kinase activity of the chimeric protein. Multiple proteins have been identified as downstream targets of $\mathrm{Bcr}-\mathrm{A} \mathrm{bl}$. A mong these are proteins involved in the regulation of mitogenic and apoptotic pathways as well as cytoskeletal-associated proteins. Primarily, components of the Ras and phosphatidylinositol 3-kinase (PI3k) pathways are critical for Bcr-Abl-dependent transformation. Dominant interfering mutants of Grb-2, Ras, and c-Jun block Bcr-Abl-mediated transformation (Gishizky et al. 
1995; Raitano et al. 1995; Sawyers et al. 1995; Cortez et al. 1996). Grb-2, Ras, and c-Jun are components of the same signal ing pathway, thereby emphasizing the essential role of this pathway in the transmission of the BcrAbl-transforming signal. Also, inhibition of PI3k and its downstream target, the Akt serine kinase, decreases transformation by Bcr-A bl (Skorski et al. 1995, 1997). In addition, interfering with the function of the transcription factors, $\mathrm{c}-\mathrm{M} \mathrm{yc}$ and NF-kB , abol ishes transformation by Bcr-Abl (Sawyers et al. 1992; Reuther et al. 1998).

Less clear is the contribution of other downstream protein targets to $\mathrm{Bcr}-\mathrm{Abl}$-dependent transformation. Although the levels of the anti-apoptotic Bcl-2 mRN A and protein are elevated in some Bcr-Abl-expressing cells (Sanchez-Garcia and Grutz 1995), it is unclear whether $\mathrm{BCl}-2$ is up-regulated in all Bcr-Abl-expressing cells, and whether its up-regulation is necessary and sufficient for the anti-apoptotic activity of Bcr-Abl (Cortez et al. 1996). Likewise, it is not known what role the increased tyrosine phosphorylation of a number of cytoskel etal-associated proteins has on the al tered adhesion and the overall transforming properties of Bcr-A bl-positive cells (Sal gia et al. 1995).

Although numerous targets for the Abl kinases have been identified, only a few of these have been shown to be important in modulation of the Abl-transforming potential (Gotoh and Broxmeyer 1997). Recently, we and other researchers identified a family of $\mathrm{Abl}$-interactor (Abi) proteins that bind specifically to both the $\mathrm{SH} 3$ and carboxy-terminal proline-rich sequences of $\mathrm{Abl}$ (Dai and Pendergast 1995; Shi et al. 1995). Two distinct, yet highly related genes, abi-1 and abi-2, were identified and cloned. The corresponding protein products share overal I $69 \%$ identity with the greatest homology observed in the amino-terminal homeobox-like domain, proline-rich sequences, and the carboxy-terminal SH3 domain. The Abi proteins are substrates of the Abl kinases. Significantly, Abi proteins antagonize the oncogenic activity of Abl in fibroblasts. Overexpression of Abi-1 potently suppresses the transforming activity of viral Abl (v-A bl) in N IH-3T 3 fibroblasts (Shi et al. 1995). Furthermore, coexpression of a truncated form of Abi-2 with c-Abl activates the oncogenic potential of c-Abl (Dai and Pendergast 1995). These and other data (Wang et al. 1996; Biesova et al. 1997) suggest that the full-length Abi proteins may function as growth inhibitors in mammalian cells.

Inactivation of molecules that function as growth inhibitors/tumor suppressors is a common event in a large number of cancers (Cordon-Cardo 1995). As illustrated for p53 and pRb, the activity of the tumor suppressors may be abrogated by mutations of the corresponding DNAs or by the sequestration of the tumor suppressor proteins by specific viral or cellular proteins. Increasing evidence is accumulating that implicates selective proteolysis in the functional inactivation of tumor suppressor proteins (Deshaies 1995; Haupt et al. 1997; Kubbutat et al. 1997). In particular, ubiquitin-dependent proteolysis appears to play a role in this process. Protein degradation by the ubiquitin pathway involves the covalent attachment of multiple ubiquitin polypeptides to the substrate protein, followed by the degradation of the polyubiquitinated substrate by the $26 \mathrm{~S}$ proteasome, a large ATP-dependent multienzyme complex (Varshavsky 1997). Several proteins that function as growth inhibitors/tumor suppressors have been reported to be degraded through ubiquitin-dependent proteolysis. A mong these are p53 and the cyclin-dependent kinase inhi bitors Siclp, Farlp, and p27 (Pagano et al . 1995; Feldman et al. 1997; Haupt et al. 1997; Henchoz et al. 1997; Kubbutat et al. 1997; Skowyra et al. 1997; Verma et al. 1997).

Here we show that oncogenic forms of the Abl and Src nonreceptor tyrosine kinases el icit the destruction of the Abi proteins by the ubiquitin-dependent proteasome machinery. The elimination of the Abi proteins by the oncogenic tyrosine kinases occurs through a novel Ras-independent pathway that is initiated by the constitutive tyrosine kinase activity of the oncoproteins. Significantly, the expression of A bi proteins is lost in cell lines and bone marrow cells from $\mathrm{Ph}^{1}$-positive leukemia patients. These findings suggest that loss of Abi proteins may play a role in oncogenesis and implicates ubiquitindependent proteolysis in tumor progression.

\section{Results}

Bcr-Abl down-regulates Abi expression in hematopoietic cells

To understand the role of Abi proteins in Abl-mediated transformation, we investigated the expression of Abi proteins in normal hematopoi etic cells as well as in cells transformed by the oncogenic Bcr-Abl fusion protein. The $\mathrm{Bcr}-\mathrm{Abl}$ gene was introduced into the pro-B BaF3 cell line and the multipotent myeloid progenitor 32D cell line. Both cell types are dependent on interleukin 3 (IL-3) for growth and survival. Expression of Bcr-Abl in BaF3 and 32D cells induces cellular transformation, confers cytokine-independent growth, and blocks apoptosis (Cortez et al. 1995, 1996, 1997). Abi proteins are expressed in BaF3 and 32D cells and migrate as a doublet of 60 and 65 kD (Fig. 1A, lane 1). Because of the strong homology between Abi 1 and Abi 2, the available antiAbi antibodies cannot distinguish between the two proteins and therefore, we will refer to these protein bands as Abi. Surprisingly, little if any Abi protein could be detected in BaF3 cells transformed with p185 Bcr-Abl (Fig. 1A, lanes 2,3). Similar findings were obtained in 32D cells transformed by Bcr-Abl. These results indicate that the expression of the oncogenic Bcr-Abl tyrosine kinase down-regulates the expression of Abi proteins. Consistent with this notion, the expression of HAtagged exogenous Abi 2 in 32D cells is also down-regulated by Bcr-Abl in the same manner as that of the endogenous Abi proteins (data not shown). The Bcr-Ablmediated down-regulation of $\mathrm{Abi}$ expression requires $\mathrm{Bcr}-\mathrm{A} \mathrm{bl}$ tyrosine kinase activity, as the expression of the kinase-deficient mutant p185 K671R Bcr-Abl (Cortez et al. 1995) failed to down-regulate A bi expression (Fig. 1A, lane 4). To determine whether the loss of Abi expression in Bcr-A bl-transformed hematopoi etic cells is caused by 


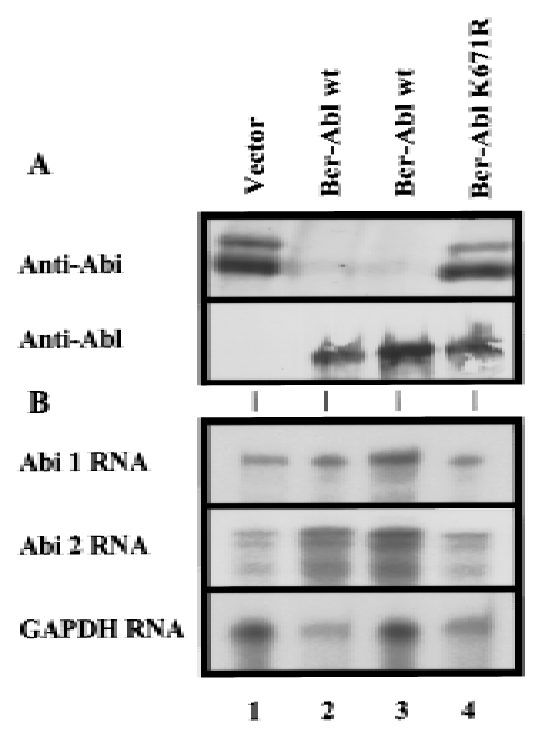

Figure 1. The oncogenic Bcr-A bl tyrosine kinase down-regulates $\mathrm{Abi}$ protein expression in BaF3 cells. (A) Loss of Abi protein with p185Bcr-Abl expression. BaF3 cells $\left(2 \times 10^{6}\right)$ were infected (lanes 1,3,4) with the indicated retroviral expression vectors or stably transfected (lane 2) with the indicated plasmid. A bi proteins were detected by immunoblotting with polyclonal 5421 anti-A bi antibodies (top). Bcr-Abl (lanes 2,3) or Bcr-Abl (K671R) (lane 4) protein was detected by immunoblotting with monoclonal anti-Abl antibody (lower). (B) Bcr-Abl expression does not alter abi 1 or abi 2 mRNA levels. abi 1, abi 2, or GAPDH antisense RNA probes were protected against RN ase digestion by BaF3 total RN A. ${ }^{35} \mathrm{~S}$-Label ed protected probes were electrophoresed on acrylamide/urea gels and detected by autoradiography.

a decrease in the transcription of abi genes, Northern blot analysis and RN ase protection assays were performed. BaF3 cells express message for both abi 1 and abi 2 (Fig. 1B, lane 1). No significant change in the abi 1 and abi 2 mRA levels, however, was observed among cells expressing the vector control, wild-type p185 Bcr-A bl, or the p185 K671R Bcr-Abl mutant (Fig. 1B, cf. Ianes 1-4). This suggests that Bcr-A bl down-regulates abi expression by a mechanism other than transcriptional regulation.

Bcr-Abl down-regulates Abi expression through the ubiquitin-proteasome pathway

The oncogenic Bcr-Abl proteins down-regulate Abi expression without significantly reducing the level of abi transcripts. This suggests that the down-regulation may occur post-translationally. An increasing number of celIular processes have been shown to be critically dependent on the control of protein abundance catalyzed by the ubiquitin-dependent proteasome pathway (Deshai es 1995). Therefore, we tested whether the down-regulation of Abi expression by Bcr-Abl uses this pathway. First, we examined whether the down-regulation of Abi proteins by Bcr-A bl is caused by increased instability of the pro- teins. To this end we synthesized ${ }^{35} \mathrm{~S}$-labeled Abi 2 in vitro using a rabbit reticulocyte lysate (RRL) and tested its stability in the presence or absence of in vitro-translated Bcr-A bl. The RRL system has been used commonly as the source of active ubiquitinating enzymes and proteasome complexes (N ielsen et al. 1997; Pagano et al. 1997). In the absence of Bcr-Abl, Abi 2 was relatively stable. In contrast, in the presence of Bcr-Abl Abi 2 was degraded rapidly in the RRL (Fig. 2, cf. lanes 3 and 6). This suggests that Bcr-A bl increases Abi protein instability. Consistent with this, we found that addition of ATP $\gamma$ S, a nonhydrolyzable ATP analog that prevents degradation of ubiquitinated proteins by the proteasome but does not prevent their ubiquitination, blocked Abi 2 degradation in RRL system (Fig. 2, lane 7).

We then tested whether the down-regulation of $A b i$ proteins by $\mathrm{Bcr}-\mathrm{Abl}$ in hematopoietic cells is dependent on the ubiquitin-proteasome pathway. BaF3 cells transfected with either a control vector or an expression vector for p185 Bcr-Abl were treated with two specific inhibitors of the ubiquitin-proteasome machinery, LLnL (N-acetyl-L-leucinyl-L-leucinyl-L-norleucinal) and lactacystin (A berle et al. 1997). As shown by Western blot analysis, LLnL and lactacystin inhibited the down-regulation of A bi expression in Bcr-Abl-expressing cells (Fig. $3 \mathrm{~A}$, lanes 5,6). Treatment of BaF3 cells expressing p185 $\mathrm{Bcr}-\mathrm{A}$ bl with LLnL and lactacystin resulted in the accumulation of 60- and 65-kD Abi proteins, as well as immunoreactive Abi proteins with a slower mobility in SDS gels. The slower mobility bands may represent Abi proteins that are modified during the process of ubiquitin-mediated proteolysis. Interestingly, the Abi proteins, in particular the slower mobility forms, also accumulated to higher levels in the control $\mathrm{BaF} 3$ cells treated with LLnL and lactacystin (Fig. 3A, Ianes 2,3). This suggests that Abi expression in normal cells may also be regulated, at least in part, by ubiquitin-mediated proteolysis. We then examined whether Abi proteins are targets for ubiquitination. A plasmid expressing an HAtagged Abi 2 was transfected into Bosc 23 cells in the

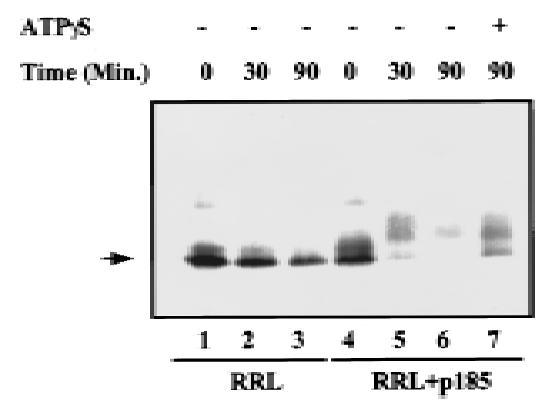

Figure 2. In vitro degradation of $\mathrm{Abi} 2$ is stimulated by p185Bcr-Abl and is ATP dependent. Abi 2 was synthesized in the presence of $\left[{ }^{35} \mathrm{~S}\right] \mathrm{methionine}$ using a coupled transcriptiontranslation kit (Promega). The labeled A bi 2 was incubated in a protein-degradation reaction mix with or without unlabeled p185Bcr-Abl, and with or without ATP $\gamma$ S, as indicated. Samples (equal volume) were removed at indicated time points and analyzed by SDS-PAGE and fluorography. 
A

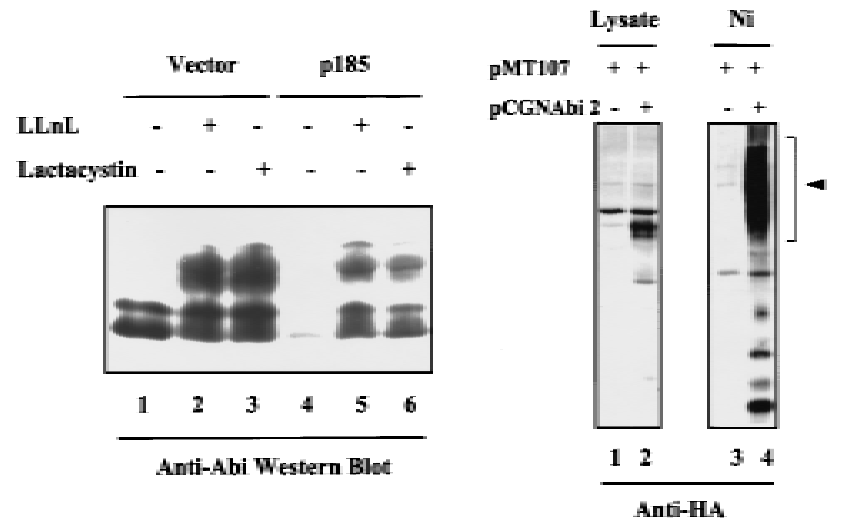

Figure 3. Bcr-Abl down-regulates $A$ bi expression through an ubiquitin-dependent proteolysis pathway. (A) Proteasome-specific inhibitors LLnL and lactacystin inhibit Bcr-Abl-induced Abi down-regulation. BaF3 cells transfected by vector alone (lanes 1-3) or expression vector encoding p185 Bcr-Abl (lanes 4-6) were untreated (lanes 1,4) or treated with $50 \mu \mathrm{M} \mathrm{LLnL}$ (lane $2,5)$ or $10 \mu \mathrm{m}$ lactacystin (lanes 3,6$)$ for $8 \mathrm{hr}$. Cells $\left(2 \times 10^{6}\right)$ were lysed in SDS sample buffer and subjected to Western bl ot analysis with 5421 anti-Abi antibodies. (B) Abi 2 is ubiquitinated in Bosc 23 cells. Bosc 23 cells were cotransfected with pMT 107, a plasmid expressing $\mathrm{His}_{6}$-tagged ubiquitin, plus either pCGN control plasmid (lanes 1,3 ) or pCGN-Abi 2 plasmid encoding HA-tagged human A bi 2 (lanes 2,4). Total cell lysates (Ianes 1,2) or ubiquitin substrate conjugates that were affinity precipitated by $\mathrm{Ni}^{2+}$ chelate chromatography (Ianes 3,4 ) were subjected to Western blot analysis with anti-HA monoclonal antibody. The position of ubiquitinated Abi 2 is indicated by an arrowhead.

presence of an expression plasmid encoding $\mathrm{His}_{6}$-tagged ubiquitin (Treier et al. 1994). The $\mathrm{His}_{6}$-tagged ubiquitinated proteins were purified by $\mathrm{N} \mathrm{i-agarose} \mathrm{chromatog-}$ raphy (T reier et al. 1994; A berle et al . 1997) and subjected to Western blot analysis with monoclonal antibody to $\mathrm{HA}$ to detect the HA-tagged Abi 2 protein. As shown in Figure 3B, Abi 2 is ubiquitinated.

\section{O ncogenic Src tyrosine kinase down-regulates Abi expression}

We then wanted to test whether Abi proteins could al so be down-regulated by expression of other oncogenic tyrosine kinases such as v-Src. A BaF3 cell line transfected with a zinc-inducible v-Src expression plasmid (Canman et al. 1995) was used in this experiment. The cells were treated with or without zinc for $8 \mathrm{hr}$ to induce v-Src expression and cell lysates were subjected to Western bl ot analysis with either A bi (Fig. 4A, top) or V-Src (Fig. $4 A$, bottom) specific antibodies. Expression of $\mathrm{v}$-Src was increased dramatically with the addition of zinc and the increased expression of v-Src correlated with a dramatic reduction of Abi expression (Fig. 4A, cf. lane 3 to lane 4). Thus, like Bcr-Abl, the oncogenic v-Src tyrosine kinase also down-regulates $\mathrm{Abi}$ expression in $\mathrm{BaF} 3$ cells. To determine whether the $\mathrm{v}$-Src induced down-regulation of
Abi expression is mediated by the ubiquitin-proteasome degradation pathway, we examined the effect of LLnL on Abi expression in v-Src-expressing BaF3 cells. v-Srctransfected cells were incubated with zinc in the presence or absence of LLnL. Zinc induced expression of $\mathrm{v}$ Src (Fig. 4B, lanes 5,6), regardless of the presence or absence of LLnL. Down-regulation of $A$ bi expression in cells treated with LLnL was completely inhibited compared with cells without LLnL treatment (Fig. 4B, cf. lanes 5 and 6). This result demonstrates that v-Src downregulates $\mathrm{Abi}$ expression through ubiquitin-mediated proteolysis.

Bcr-Abl-mediated down-regulation of A bi expression is Ras independent

Oncogenic Bcr-Abl proteins elicit cellular transformation through multiple signal transduction pathways (Gotoh and Broxmeyer 1997). Previously, we and other investigators have shown that Ras function is activated
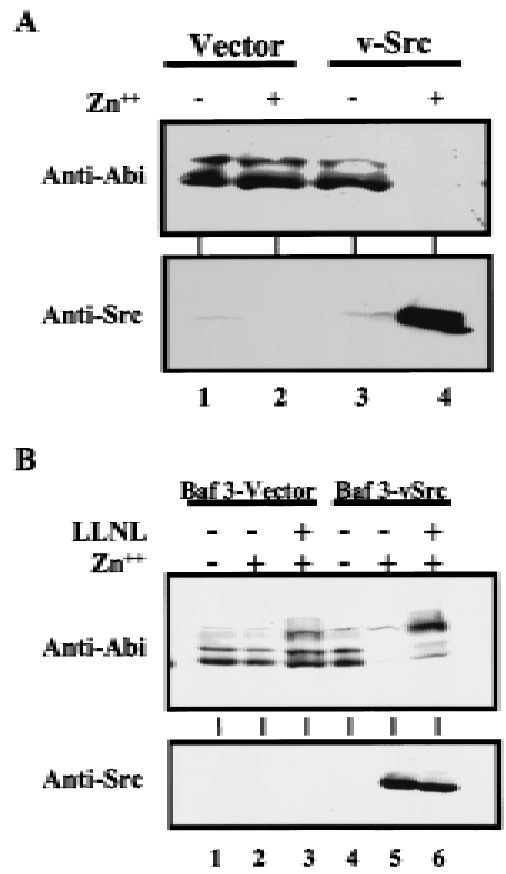

Figure 4. $\mathrm{v}$-Src down-regulates Abi expression through an ubiquitin-dependent proteolysis pathway. (A) Oncogenic v-Src tyrosine kinase down-regulates $\mathrm{A}$ bi expression. BaF3 cells transfected by vector alone (lanes 1,2 ), or zinc-inducible v-Src-expressing vector (lanes 3,4) were treated with or without $75 \mu \mathrm{m}$ $\mathrm{ZnCl}_{2}$ for $8 \mathrm{hr}$, as indicated. Total cell lysates $\left(2 \times 10^{6}\right)$ were subjected to Western blot analysis with either 5421 anti-Abi antibodies (top) or anti-v-Src antibodies (bottom). (B) Proteasome inhibitor LLnL inhibits v-Src-induced down-regulation of Abi expression. BaF3 cells transfected by vector alone (lanes 1-3) or zinc-inducible v-Src expression vector (lanes 4-6) were treated with (lanes 3,6) or without (lanes 1,2,4,5) $50 \mu \mathrm{N}$ LLnL for $1 \mathrm{hr}$. $\mathrm{ZnCl}_{2}(75 \mu \mathrm{M})$ was then added as indicated, and cells were incubated for an additional $7 \mathrm{hr}$. Cells $\left(2 \times 10^{6}\right)$ were lysed in SDS sample buffer and subjected to Western bl ot analysis with either 5421 anti-Abi (top) or anti-v-Src antibodies (bottom). 
in Bcr-Abl-transformed cells and it is a necessary component for Bcr-A bl-medi ated transformation (Pendergast et al. 1993; Puil et al. 1994; Cortez et al. 1995, 1996). Studies on photoreceptor cell differentiation of the Drosophila eye have shown that activation of the Ras/Map kinase-signaling cascade results in the ubiquitin-mediated degradation of Tramtrack (TTK) (Li et al. 1997; Tang et al. 1997), a transcriptional repressor of neuronal cell fates, as well as of the transcription factor YAN (Rebay and Rubin 1995), a general inhibitor of differentiation of many cell types in the Drosophila eye. Therefore, we examined whether the Bcr-Abl-mediated down-regulation of Abi expression is Ras dependent. We used p185 and p210 Bcr-A bl-transformed 32D cells that coexpress a dominant-negative form of Ras, Ras Asn 17 (Feig and Cooper 1988), under the control of a glucocorticoid responsive promoter. Previously, we have shown that the inducible expression of dominant- negative Ras Asn 17 blocks Bcr-Abl from activating Ras in these cells (Cortez et al. 1996). Cells were treated with dexamethasone for $24 \mathrm{hr}$ to obtain high-level expression of dominant-negative Ras Asn 17. The expression of Bcr-Abl (data not shown), dominant -negative Ras (Fig. 5A, lanes 1-4), and A bi proteins (Fig. 5A, lanes 5-11) was evaluated by Western bl ot analysis. Despite overexpression of dominantnegative Ras Asn 17, the expression of Abi proteins in the dexamethasone-treated cells (Fig. 5A, lanes 9,11) is down-regulated to low levels similar to nontreated cells (Fig. 5A, lanes 8,10) or control cells that express Bcr-Abl alone (Fig. 5A, lanes 6,7). Because Raf is an immediate downstream component of Ras in the Ras/Map kinase signaling cascade, we tested whether the enforced expression of an activated Raf protein kinase would elicit the down-regulation of $\mathrm{A}$ bi expression in $\mathrm{BaF} 3$ cells. $\mathrm{A}$ BaF3 cell line that inducibly expresses an activated form of human c-Raf (c-Raf-BXB) (C anman et al. 1995) from a zinc-responsive promoter was grown in the presence or absence of zinc. Zinc induced the expression of c-RafBXB (Fig. 5B). Consistent with the findings in Figure 5A, the enforced expression of the activated Raf did not affect the expression of Abi protein (Fig. 5B, cf. lane 3 to Iane 4). Taken together, our results demonstrate that down-regulation of Abi expression by oncogenic Bcr-A bl is Ras and Raf independent.

The expression of Abi proteins is lost in cell lines and bone marrow cells from Philadelphia chromosome-positive leukemia patients

The finding that $\mathrm{Bcr}-\mathrm{A}$ bl down-regulates the expression of Abi proteins in BaF3 cells and 32D cells prompted us to test whether the Abi protein levels are also downregulated as a consequence of Bcr-A bl expression in primary bone marrow cells, the natural target of the oncogenic Bcr-Abl tyrosine kinase. Mouse bone marrow cells were infected with $\mathrm{Bcr}-\mathrm{Abl}$ and the expression of $\mathrm{Abi}$ proteins was examined by Western blotting (Fig. 6A, bottom). Consistent with the results observed in $\mathrm{BaF} 3$ and 32D cells (Fig. 6A, lanes 1,2), infection of bone marrow cells with $\mathrm{Bcr}-\mathrm{Abl}$ retrovirus results in a loss of $\mathrm{Abi}$ ex-
A

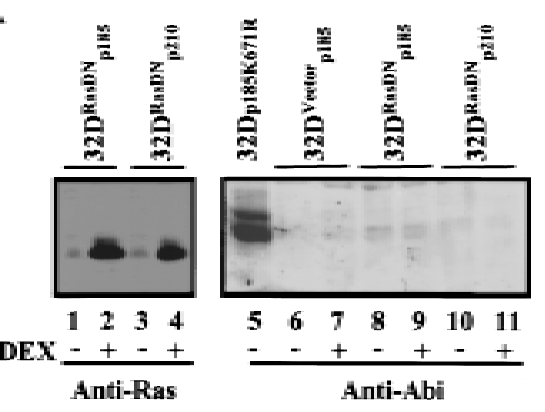

B

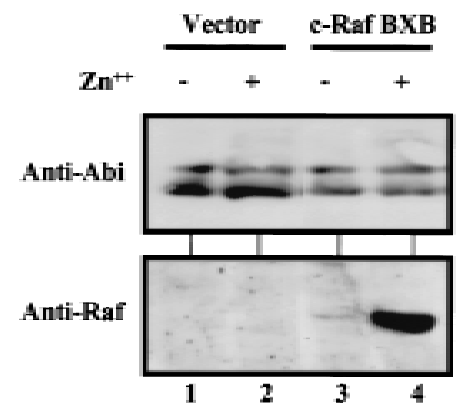

Figure 5. Bcr-A bl-mediated down-regulation of Abi expression is independent of Ras signaling. (A) Expression of a dominantnegative Ras, Ras Asn 17, failed to block Bcr-Abl-mediated down-regulation of Abi expression. 32D cells expressing a control plasmid $\left(32 D^{\text {Vector, }}\right.$ lanes 6,7$)$ or a plasmid inducibly expressing Asn 17 Ras (32D RasDN, lanes 1-4 and 8-11) were infected with retroviruses carrying either the p185Bcr-Abl (lanes 1,2 , and 6-9) or p210Bcr-Abl (lanes $3,4,10,11$ ) oncogenes. The cells were treated with or without $50 \mathrm{~nm}$ dexamethasone for 24 $\mathrm{hr}$, as indicated, to induce the expression of Ras Asn 17. A control 32D cell line infected with a retrovirus encoding a kinase-deficient p185Bcr-Abl mutant was also included (lane 5). Cells $\left(2 \times 10^{6}\right)$ were lysed in SDS sample buffer and subjected to Western blot analysis with either anti-Ras antibody (pan Ras, Santa Cruz) (lanes 1-4) or 5421 anti-A bi antibody (lanes 5-11) as indicated. (B) Expression of an activated form of c-Raf does not down-regulate Abi expression. BaF3 cells transfected with either vector al one (lanes 1,2), or an inducible expression vector encoding activated c-Raf, C-Raf-BXB, were treated with or without $75 \mu \mathrm{M} \mathrm{ZnCl}$ for $8 \mathrm{hr}$ as indicated. Cells $\left(2 \times 10^{6}\right)$ were lysed in SDS sample buffer and subjected to Western blot analysis using 5421 anti-Abi antibody (top) or anti-Raf antibody (Santa Cruz, bottom).

pression (Fig. 6A, cf. lanes 3 and 4, bottom) that correlates with the expression of Bcr-Abl protein (Fig. 6A, top). Then we tested whether the expression of Abi proteins is al so reduced in bone marrow cells from patients with $\mathrm{Ph}^{1}$-positive human leukemias. The Abi proteins were shown to be expressed in bone marrow cells from either normal human samples or a $\mathrm{Ph}^{1}$-negative leukemia patients (Fig. 6B, lanes 3,4 ). In contrast, A bi protein expression was lost in bone marrow cells from a $\mathrm{Ph}^{1}$ positive patient with $\mathrm{ALL}$ or from a $\mathrm{Ph}^{1}$-positive patient with $C M L$ in the blast crisis phase of the di sease (Fig. 6B, lanes 1,2). K562 and MEG01 are cell lines derived from patients with CML in the blast crisis phase of the dis- 


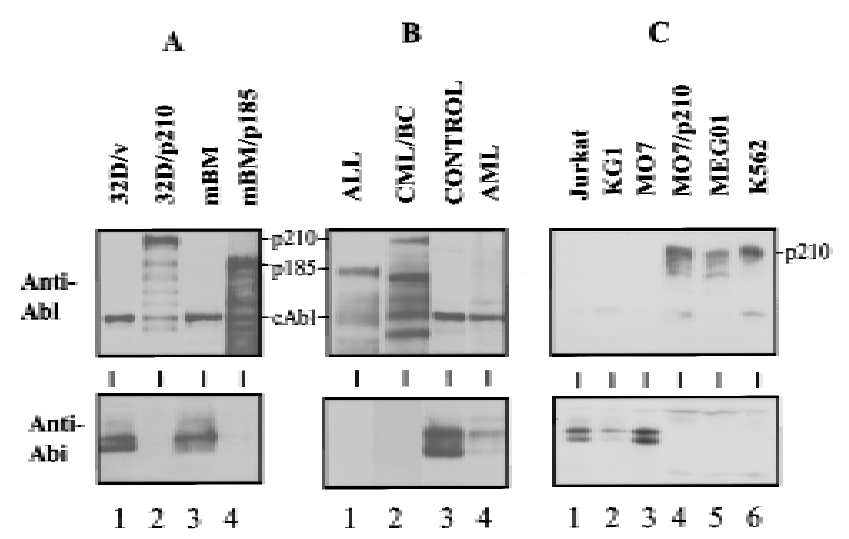

Figure 6. Expression of Abi proteins is lost in Bcr-Abl-transformed primary bone marrow cells and cells from $\mathrm{Ph}^{1}$-positive leukemia patients. Western blots were performed to compare Abl immunoreactivity (top) with Abi protein expression (bottom) in murine cells, human leukemia samples, and human cell lines. (A) 32D cells were infected with retroviral constructs containing vector al one (32D/v, lane 1 ) or p210 Bcr-A bl (32D / p210, lane 2). Primary mouse bone marrow (mBM, lane 3) was infected with a retroviral construct containing p185 Bcr-Abl (mBM/ p185, lane 4) and analyzed after 18 days of selection with G418. (B) Bone marrow was obtained from patients with $\mathrm{Ph}^{1}$-positive acute lymphoblastic leukemia (ALL, Iane 1 ), or with $\mathrm{Ph}^{1}$-positive chronic myelogenous leukemia in blast crisis (CML/BC, lane 2), and was compared to normal bone marrow (control, lane 3) and bone marrow obtained from a patient with $\mathrm{Ph}^{1}$-negative acute myelogenous leukemia ( $\mathrm{AML}$, lane 4). (C) $\mathrm{Ph}^{1}$-negative human leukemia cell lines (Jurkat and KG1, lanes 1,2) and human myeloid cell line MO7 (lane 3) were compared to $\mathrm{Ph}^{1}$ positive cell lines (MEG01 and K562, lanes 5,6) or to a $\mathrm{Ph}^{1}$ negative cell line infected with retrovirus containing p210 Bcr/ Abl (M 07/p210, lane 4).

ease. Therefore, we compared these cell lines with a human myeloid cell line (MO7e), a cell line from a $\mathrm{Ph}^{1}$ negative acute myelogenous leukemia patient (KG1), and a cell line from a T-cell leukemia patient (Jurkat), for the expression of Abi proteins. Examination of the mRN As for abi 1 and abi 2 by reverse transcriptase PCR reveal ed that they are present in all of these cell lines (data not shown). As shown in Figure 6C, expression of Abi proteins was undetectable in those cells from the $\mathrm{Ph}^{1}$-positive leukemia patients, whereas $\mathrm{A}$ bi proteins are present in the other cell lines (Fig. 6C, lanes 5,6). Consistently, the down-regulation of Abi expresion correlates with the expression of oncogenic Bcr-Abl (Fig. 6C, upper). Taken together, these data suggest that loss of Abi protein expression may be a component in the progression of Bcr-Abl-positive leukemias.

\section{Discussion}

We have identified a novel pathway downstream of the oncogenic Abl and Src nonreceptor tyrosine kinases that targets the destruction of the Abl-interacting Abi family of proteins through the ubiquitin-proteasome pathway. The down-regulation of the Abi proteins requires the tyrosine kinase activity of $A \mathrm{bl}$, and it is independent of the
Ras-Raf pathway. Significantly, the degradation of the Abi proteins appears to be selective. Other molecules known to be degraded by the ubiquitin-dependent proteolysis pathway in response to extracellular signal s or cell cycle progression, such as $\mathrm{I} \kappa \mathrm{B} \alpha$ and the cyclin-dependent kinase inhibitor p27, are not affected by expression of oncogenic forms of Abl (Reuther et al. 1998; Z. Dai and A.M. Pendergast, unpubl.). It is likely, however, that additional proteins may be targeted for ubiquitin-dependent degradation after expression of the Abl and Src oncogenic tyrosine kinases.

It has become increasingly apparent that ubiquitin-dependent proteolysis of specific proteins is a highly regulated process. Linkage of ubiquitin to proteins that display a distinct degradation signal, results in the destruction of the ubiquitin-protein conjugate by the 265 proteasome (Varshavsky 1997). The conjugation of ubiquitin to the target protein involves a series of steps that begin with the formation of a thioester bond between ubiquitin and the ubiquitin-activating enzyme (E1). Ubiquitin is then transesterified to an ubiquitin-conjugating enzyme (UBC or E2) and subsequently transferred to the target protein, usually with the involvement of an ubi quitin protein ligase (E3). The latter is the component of the ubiquitin conjugation system that is involved in substrate recognition (Varshavsky 1997). Several ubiquitin-dependent degradation signals have been identified to date. Regulated destruction of target proteins is usually dependent on phosphorylation, interaction with specific proteins, or both. M ost of the phosphorylation-regulated degradation signals identified to date are mediated by serine/threonine kinases (Rebay and Rubin 1995; Henchoz et al. 1997; M aniatis 1997; Verma et al. 1997) . Although the tyrosine kinase activity of Bcr-Abl is absolutely required for $A$ bi degradation, it is not clear at present whether direct tyrosine phosphorylation of the Abi proteins is critical for their proteolytic degradation. It is possible that the activated tyrosine kinases may induce Abi degradation through the phosphorylation of serine/ threonine residues on $\mathrm{Abi}$ by protein kinases activated downstream of the oncogenic tyrosine kinases. Alternatively, the activated tyrosine kinases may induce the formation of a complex between Abi proteins and specific cellular proteins that target Abi for degradation. These two types of degradation signals are not mutual ly exclusive. Multiple serine, threonine, and tyrosine residues arefound in the A bi proteins that may be phosphorylated by various protein kinases. Abi protein also contain sequences rich in proline, glutamic acid, serine, and threonine, designated as PEST, which have been found in many proteins that are targeted for ubiquitin-dependent degradation (Deshaies 1995; Rechsteiner and Rogers 1996). However, PEST sequences al one are not sufficient to identify those proteins that are targets of ubiquitindependent degradation (Varshavsky 1997). Extensive mutagenesis of the Abi proteins is necessary to identify those residues critical for their ubiquitin-dependent degradation. The availability of an in vitro degradation assay for the A bi proteins (Fig. 2) will facilitate the identification of the residues on Abi important for ubiquitin-de- 
pendent degradation and will permit the isolation of the protein recognition complex that targets Abi for degradation by the proteasome.

The finding that Abi protein expression is lost in cells after expression of the transforming Bcr-Abl and v-Src tyrosine kinases, together with the discovery that Abi proteins are absent in cell lines and bone marrow cells isolated from patients with aggressive Bcr-Abl-positive leukemias, suggests that loss of Abi proteins by the ubiquitin-proteasome pathway may be a component in the progression of Bcr-Abl-positive leukemias and possibly other cancers. The irreversible nature of proteolysis makes this process uniquely suited for the el imination of growth inhibitory molecules during tumor progression. Indeed, several tumor-suppressor and growth-inhibitory proteins have been shown to be degraded by ubiquitindependent proteolysis. Among these is the p53 tumorsuppressor protein that is targeted for degradation by the human papilloma virus E6 oncoprotein (Scheffner et al. 1990) and the cellular M dm 2 protein (Haupt et al . 1997; Kubbutat et al. 1997). Similarly, SHP-1, a protein tyrosine phosphatase that is implicated in receptor-mediated inhibitory signals, is targeted for ubiquitin-dependent degradation by an activated form of the Kit receptor tyrosine kinase (Piao et al. 1996). More recently, another link between tumor progression and increased proteasome-dependent degradation was provided by the finding that the cell cycle inhibitor p27 is targeted for ubiquitindependent degradation in aggressive colorectal carcinomas (Loda et al. 1997). These examples show that selective degradation of proteins that participate in the control of growth inhibitory pathways represents an alternative mechanism for their inactivation without the involvement of mutations or deletions in the corresponding genes.

Although our findings and those of other published reports are consistent with the hypothesis that Abi proteins function as growth inhibitors/tumor suppressors, an alternative role for these proteins, which cannot be ruled out at the present time, is that Abi proteins are downstream substrates of the oncogenic tyrosine kinases. The phosphorylated Abi proteins may transduce a signal from the oncogenic tyrosine kinases. A bi activation may be coupled to Abi destruction through the ubiquitin-proteasome pathway. The tightly coupled activation and the proteasome-dependent destruction of a protein has been documented for the p58 component of the yeast kinetochore Cbf 3 protein complex (Kaplan et al. 1997). The p58 protein is activated by phosphorylation as assayed by DNA-binding activity and subsequently it is degraded by the proteasome in a ubiquitin-dependent step. The phosphorylation and degradation of p58 are tightly coupled events that require the product of the SKP1 gene p23 Skp1 (Kaplan et al. 1997). It has been proposed that p23 Skpl functions as an adaptor that recruits a protein kinase by binding to both p58 and the unknown kinase. Also, p23 Skp1 is a component of the E3 ubiquitin ligase complex that targets p58 to the proteasome machinery. In this manner p58 is regulated positively by phosphorylation and regulated negatively by ubiquitin-dependent proteolysis. Linked activation and negative regulation of cellular proteins in response to phosphorylation has al so been reported in mammal ian cells for the STAT 1 transcription factor (Kim and $\mathrm{Ma}$ niatis 1996). Activated STAT 1 has been shown to be regulated negatively by the ubiquitin-proteasome pathway. Tyrosine phosphorylation of STAT 1, which is induced by treatment of cells with interferon- $\gamma$, is required for its nuclear translocation and activation of transcription and it is also required for STAT 1 ubiquitination and subsequent degradation. A similar role for the phosphorylation of $\mathrm{Abi}$ proteins may exist in cells transformed by the activated Abl an Src tyrosine kinases.

The finding that Abi proteins are targeted for degradation by both oncogenic $\mathrm{Abl}$ and Src suggests that the activities of these two tyrosine kinases may be linked or alternatively, that they may regulate independently the function of specific common target proteins such as A bi. The data al so raise the possibility that Abi proteins may be targeted for degradation in other human cancers where the Src family of nonreceptor tyrosine kinases are activated constitutively. Future work will be geared toward elucidating the cellular components of this novel pathway and the identification of additional targets of ubiquitin-dependent degradation triggered by the activity of oncogenic protein tyrosine kinases.

\section{Materials and methods}

Cell culture and retroviral infection

BaF3 cells and 32D cells were grown in RPMI containing $10 \%$ fetal calf serum (FCS) and 10\% WEHI-conditioned media (WEHI-CM) as a source of IL-3. Stable mass populations of cells expressing bcr-abl transgenes were generated by retroviral infection as previously described (Cortez et al. 1995). BaF3 cell lines expressing v-Src and c-Raf-BXB (Canman et al. 1995) were grown in RPMI containing 10\% FCS and 10\% WEHI-CM. To induce the expression of $\mathrm{V}$-Src and c-Raf-BXB, cells were treated with $75 \mu \mathrm{M} \mathrm{ZnCl}$ for $8 \mathrm{hr}$. To inhibit ubiquitin-dependent proteolysis, cells were treated with either $10 \mu \mathrm{m}$ lactacystin or 50 $\mu \mathrm{M}$ LLnL for $8 \mathrm{hr}$. Cells were washed once with PBS and lysed directly in SDS sample buffer [50 mM Tris- $\mathrm{HCl}(\mathrm{pH} 6.8), 2 \%$ SDS, $10 \%$ glycerol, $5 \% \quad \beta$-mercaptoethanol] for Western blot analysis.

\section{Anti-Abi antibodies}

Rabbit polyclonal antibodies 5421 and 4575 anti-Abi were raised to a recombinant GST-A bi $2 \Delta 1-100$ fusion protein and a synthetic A bi 2 peptide (amino acids 318-329), respectively. Antibodies were affinity purified by standard techniques (Harlow and Lane 1988).

\section{RNA analysis}

abi 1 and abi 2 mRN A levels were determined by RN ase protection assays. Total RNA was isolated from BaF3 cells using TRIzol reagent (GIBCO BRL) or the RN easy Mini Kit (Qiagen) as directed by each of the manufacturers. The protocols for these two methods were followed as directed. Antisense probes for abi 1 and abi 2 mRN A were generated by in vitro transcription with T3 RNA polymerase (Stratagene). abi 1 probe was transcribed from a linearized template containing the T 3 promoter 
from the pPCR-Script Amp SK(+) plasmid (Stratagene) and a 244-nucleotide fragment of abi 1 cDN A. abi 2 probe was generated from linearized pBlueScript II SK $+/-$ (Stratagene) plasmid containing a 435-bp fragment of abi 2 mouse genomic DN A composed of a 48-bp intronic region and 397 nucleotides from a single exon. The probe for mouse GAPDH RNA was generated from the pTRI-GAPDH mouse linear fragment (Ambion) using T3 RN A polymerase. RN ase protection experiments were carried out in accordance with instructions provided by the manufacturer (Ambion). Hybridization of probes to RNA protected the probes from digestion with RN ase A plus T 1 (Ambion). To detect abi 2 by RN ase protection, $30 \mu \mathrm{g}$ of total RN A was used per lane. Twenty micrograms of RN A was used for abi 1 and 10 $\mu \mathrm{g}$ of RNA was used for GAPDH. After digestion, protected probes for abi 1, abi 2, and GAPDH were analyzed in separate lanes of $6 \%$ acrylamide/urea gels. ${ }^{35} \mathrm{~S}$-Labeled protected fragments were detected by autoradiography.

\section{Analysis of Abi expression in bone marrow cells}

P185-expressing primary mouse bone marrow cells were generated by retroviral infection as described (Cortez et al. 1995). M ouse bone marrow was obtained by flushing the femurs of 3to 4-week-old male BALB/c mice (Charles River Labs) with IMDM containing $2 \%$ FCS and either was used for retroviral infection followed by G418 selection as described (M cLaughlin et al. 1989), or processed through two rounds of ammonium chloride lysis, lysed in $2 \times$ SDS sample buffer and used directly for Western blot analysis using antibodies against the Abl kinase domain (8E9, Pharmingen) or Abi-2. Bone marrow samples from leukemia patients were obtained from the SWOG Human Tissue Bank (University of N ew M exico) or the Duke Human Tissue Bank (Duke University Medical Center). N ormal bone marrow was obtained after informed consent from patients undergoing autol ogous bone marrow transplantation for nonhematological malignancies. After Ficoll density gradient centrifugation (Sigma), light density human bone marrow cells were re suspended in PBS containing $0.01 \mathrm{mg} / \mathrm{ml}$ aprotinin (Boehringer Mannheim), $5 \mathrm{~mm}$ benzamidine (Sigma), and $1 \mathrm{mg} / \mathrm{ml} \mathrm{AEBSF}$ ("Pefabloc SC" Boehringer M annheim), then lysed with 2×SDS sample buffer for Western blot analysis. Mouse myeloid and mouse and human bone marrow samples were normalized to give roughly equal levels of $\mathrm{Abl}$ immunoreactivity.

\section{In vitro degradation assay}

${ }^{35} \mathrm{~S}$-Labeled human A bi 2 was produced using RRL and plasmid PT TT3-A bi 2 with a coupled transcription-translation kit (Promega). The transcription-translation reaction was performed at $30^{\circ} \mathrm{C}$ for $120 \mathrm{~min}$ in the presence of $\left[{ }^{35} \mathrm{~S}\right]$ methionine, as indicated by the manufacturer. To produce unlabeled p185Bcr-Abl, the transcription-translation reaction was performed using plasmid pGEMp185Bcr-Abl in the presence of a complete amino acid mix. Protein stability was analyzed by incubating 3 $\mu \mathrm{l}$ of ${ }^{35} \mathrm{~S}-\mathrm{label}$ ed A bi 2 in $50 \mu \mathrm{l}$ of degradation mix [33\% RRL, 50 $\mathrm{mm}$ Tris- $\mathrm{HCl}(\mathrm{pH} 8.0), 5 \mathrm{~mm} \mathrm{M} \mathrm{gCl}, 2 \mathrm{~mm}$ dithiothreitol, $1 \mathrm{~mm}$ ATP, and $2 \mathrm{~mm}$ methionine] at $37^{\circ} \mathrm{C}$ in the presence or absence of $3 \mu \mathrm{l}$ of p185Bcr-Abl-containing lysate. Where indicated, $1 \mathrm{~mm}$ ATP was substituted with $2 \mathrm{~mm}$ ATP $\gamma$ S. The reaction was stopped by addition of an equal volume of $2 \times$ SDS sample buffer and analyzed by SDS-PAGE.

\section{Affinity precipitation}

Purification of His-tagged ubiquitin expressed transiently in Bosc 23 cells was performed following the method of Treier et al. (1994). Briefly, $48 \mathrm{hr}$ after transfection cells were lysed with $1 \mathrm{ml}$ of GTN buffer per $60-\mathrm{mm}$ dish [6 $\mathrm{M}$ guanidinium- $\mathrm{HCl}, 20$ $\mathrm{mm}$ Tris- $\mathrm{HCl}$ (pH 8.0), $200 \mathrm{~mm} \mathrm{NaCl}, 10 \mathrm{~mm}$ imidazole, $0.1 \%$ TX-100]. The lysate was sonicated with a microtipped sonifier at setting 4 for $20 \mathrm{sec}$ to reduce viscosity. Fifty microliters of $\mathrm{Ni}^{2+}$-NTA-agarose beads (Qiagen) was added and mixed for $4 \mathrm{hr}$ at room temperature. The beads were successively washed with the following solutions (pH 8.0): $1 \mathrm{ml}$ of GTN; $1 \mathrm{ml}$ of $8 \mathrm{M}$ urea, $20 \mathrm{~mm}$ Tris- $\mathrm{HCl}, 200 \mathrm{~mm} \mathrm{NaCl}, 0.1 \% \mathrm{TX}-100 ; 1 \mathrm{ml}$ of $8 \mathrm{M}$ urea, $20 \mathrm{~mm}$ Tris- $\mathrm{HCl}, 1 \mathrm{M} \mathrm{N} \mathrm{aCl}, 0.1 \% \mathrm{TX}-100 ; 1 \mathrm{ml}$ of $4 \mathrm{~m}$ urea, 20 $\mathrm{mm}$ Tris- $\mathrm{HCl}, 200 \mathrm{~mm} \mathrm{NaCl}, 0.1 \% \mathrm{TX}-100 ; 1 \mathrm{ml}$ of $1 \mathrm{~m}$ urea, 20 $\mathrm{mm}$ Tris- $\mathrm{HCl}, 200 \mathrm{~mm} \mathrm{~N} \mathrm{aCl}, 0.1 \% \mathrm{TX}-100$; and $1 \mathrm{ml}$ of $20 \mathrm{~mm}$ Tris- $\mathrm{HCl}, 200 \mathrm{~mm} \mathrm{NaCl}, 10 \mathrm{~mm}$ imidazole, $0.1 \% \mathrm{TX}-100$. The bound $\mathrm{His}_{6}$-tagged ubiquitin substrate complexes were analyzed by SDS-PAGE and Western blotting.

\section{Acknowledgments}

We thank Dr. T.M. Gilmer for BaF3 cell lines expressing v-SrC and C-Raf BXB; Dr. C.L. Willman for the human leukemia samples; Dr. N. Tonks for MO7 and M 07/p210 cell lines; Dr. J.T. Parsons for anti-v-Src antibodies; Dr. D. Bohmann for Histagged ubiquitin-expressing vector; Dr. H.S. Symonds for advice with the RN ase protection assay; and Drs. A.R. Means, X.F. Wang, and J. N evins for critical review of the manuscript. This work was supported by grants from the $\mathrm{N}$ ational Cancer Institute (CA61033 and CA 70940). Z.D. is a Special Fellow of the Leukemia Society of America. R.C.Q. is supported by the Four Schools Physician-Scientist Program, sponsored by the Lucille P. M arkey Charitable Trust. K.D.C. is supported by the M edical Scientist Training Program. D.C. was supported by Howard Hughes Medical Institute predoctoral fellowship. G.W.R. was supported by an Environmental Protection Agency Fellowship. A.M.P. is a Whitehead Scholar and a Scholar of the Leukemia Society of America.

The publication costs of this article were defrayed in part by payment of page charges. This article must therefore be hereby marked "advertisement" in accordance with 18 USC section 1734 solely to indicate this fact.

\section{References}

A berle, H., A. Bauer, J. Stappert, A. Kispert, and R. Kemler. 1997. $\beta$-Catenin is a target for the ubiquitin-proteasome pathway. EMBO J. 16: 3797-3804.

Bergold, P.J., J.Y. Wang, W.D. Hardy Jr., V. Littau, E. Johnson, and $\mathrm{P}$. Besmer. 1987. Structure and origins of the HZ2-feline sarcoma virus. Virology 158: 320-329.

Biesova, Z., C. Piccoli, and W.T. Wong. 1997. Isolation and characterization of e3B1, an eps8 binding protein that regulates cell growth. Oncogene 14: 233-241.

Canman, C.E., T.M. Gilmer, S.B. Coutts, and M.B. Kastan. 1995. Growth factor modulation of p53-mediated growth arrest versus apoptosis. Genes \& Dev. 9: 600-611.

Clarkson, B.D., A. Strife, D. Wisniewski, C. Lambek, and N. Carpino. 1997. N ew understanding of the pathogenesis of CML: A prototype of early neoplasia. Leukemia 11: 14041428.

Cordon-Cardo, C. 1995. Mutations of cell cycle regulators. Biological and clinical implications for human neoplasia. Am. J. Pathol. 147: 545-560.

Cortez, D., L. Kadlec, and A.M. Pendergast. 1995. Structural and signaling requirements for BCR-ABL-mediated transformation and inhibition of apoptosis. Mol. Cell. Biol. 15: 55315541. 
Cortez, D., G. Stoica, J.H. Pierce, and A.M. Pendergast. 1996. The BCR-ABL tyrosine kinase inhibits apoptosis by activating a Ras-dependent signaling pathway. Oncogene 13: 25892594.

Cortez, D., G. Reuther, and A.M. Pendergast. 1997. The Bcr-A bl tyrosine kinase activates mitogenic signaling pathways and stimulates G1-to-S phase transition in hematopoietic cells. Oncogene 15: 2333-2342.

Dai, Z. and A.M. Pendergast. 1995. Abi-2, a novel SH3-containing protein interacts with the c-Abl tyrosine kinase and modulates c-Abl-transforming activity. Genes \& Dev. 9: 2569-2582.

Daley, G.Q., R.A. Van Etten, and D. Baltimore. 1990. Induction of chronic myelogenous leukemia in mice by the P210bcr/ abl gene of the Philadel phia chromosome. Science 247: 824830.

Deshaies, R.J. 1995. Make it or break it: The role of ubiquitindependent proteolysis in cellular regulation. Trends Cell Biol. 5: 428-434.

Feig, L.A. and G.M. Cooper. 1988. Inhibition of NIH 3T3 cell proliferation by a mutant ras protein with preferential affinity for GDP. Mol. Cell. Biol. 8: 3235-3243.

Feldman, R.M., C.C. Correll, K.K. Kaplan, and R.J. Deshaies. 1997. A complex of Cdc4p, Skplp, and Cdc53p/cullin catalyzes ubiquitination of the phosphorylated CDK inhibitor Siclp. Cell 91: 221-230.

Gishizky, M.L., D. Cortez, and A.M. Pendergast. 1995. M utant forms of growth factor-binding protein-2 reverse BCR-ABLinduced transformation. Proc. Natl. Acad. Sci. 92: 1088910893.

Gotoh, A. and H.E. Broxmeyer. 1997. The function of BCR/ABL and related proto-oncogenes. Curr. O pin. Hematol. 4: 3-11.

Harlow, E. and D. Lane. 1988. Antibodies, a laboratory manual. Cold Spring Harbor Laboratory, Cold Spring Harbor, NY.

Haupt, Y., R. Maya, A. Kazaz, and M. Oreb. 1997. Mdm2 promotes the rapid degradation of p53. Nature 387: 296-298.

Heisterkamp, N., G. Jenster, J. ten Hoeve, D. Zovich, P.K. Pattengale, and J. Groffen. 1990. Acute leukaemia in bcr/abl transgenic mice. Nature 344: 251-253.

Henchoz, S., Y. Chi, B. Catarin, I. Herskowitz, R.J. Deshaies, and M. Peter. 1997. Phosphorylation- and ubiquitin-dependent degradation of the cyclin-dependent kinase inhibitor Farlp in budding yeast. Genes \& Dev. 11: 3046-3060.

Hochstrasser, M. 1995. U biquitin, proteasomes, and the regulation of intracellular protein degradation. Curr. Opin. Cell. Biol. 7: 215-223.

Kaplan, K.B., A.A. Hyman, and P.K. Sorger. 1997. Regulating the yeast kinetochore by ubiquitin-dependent degradation and Skplp-mediated phosphorylation. Cell 91: 491-500.

Kim, T.K. and T. Maniatis. 1996. Regulation of interferon- $\gamma-$ activated STAT 1 by the ubiquitin-proteasome pathway. Science 273: 1717-1719.

King, R.W., R.J. Deshaies, J.M. Peters, and M.W. Kirschner. 1996. How proteolysis drives the cell cycle. Science 274: 1652-1659.

Kubbutat, M.H.G., S.N. Jones, and K.H. Vousden. 1997. Regulation of p53 stability by Mdm2. Nature 387: 299-303.

Kurzrock, R., M. Shtal rid, P. Romero, W.S. Kloetzer, M. Tal pas, J.M. Trujillo, M. Blick, M. Beran, and J.U. Gutterman. 1987. A novel c-abl protein product in Philadel phia-positive acute Iymphoblastic leukaemia. Nature 325: 631-635.

Laneuville, P. 1995. A bl tyrosine protein kinase. Semin. Immunol. 7: 255-266.

Li, S., Y. Li, R.W. Carthew, and Z.C. Lai. 1997. Photoreceptor cell differentiation requires regulated proteolysis of the transcriptional repressor Tramtrack. Cell 90: 469-478.
Loda, M., B. Cukor, S.W. Tam, P. Lavin, M. Fiorentino, G.F. Draetta, J.M. Jessup, and M. Pagano. 1997. Increased proteasome-dependent degradation of the cyclin-dependent kinase inhibitor p27 in aggressive colorectal carcinomas. Nature Med. 3: 231-234.

Maniatis, T. 1997. Catalysis by a multiprotein IкB kinase complex. Science 278: 818-819.

McLaughlin, J., E. Chianese, and O.N. Witte. 1989. Alternative forms of the BCR-ABL oncogene have quantitatively different potencies for stimulation of immature lymphoid cells. Mol. Cell. Biol. 9: 1866-1874.

Melo, J.V. 1996. The diversity of Bcr-Abl fusion proteins and their relationship to leukemia phenotype. Blood 88: 23752384.

Nielsen, K.H., A.G. Papageorge, W.C. Vass, B.M. Willumsen, and D.R. Lowy. 1997. The Ras-specific exchange factors mouse Sos (mSos1) and mSos2 are regulated differently: mSos2 contains ubiquitination signals absent in mSosl. Mol. Cell. Biol. 17: 7132-7138.

Pagano, M., S.W. Tam, A.M. Theodoras, P. Beer-Romero, G.D. Sal, V. Chau, P.R. Yew, G.F. Draetta, and M. Rolfe. 1997. Role of the ubiquitin-proteasome pathway in regulation abundance of the cyclin-dependent kinase inhibitor p27. Science 269: 682-685.

Pendergast, A.M., L.A. Quilliam, L.D. Cripe, C.H. Bassing, Z. Dai, N. Li, A. Batzer, K.M. Rabun, C.J. Der, J. Schlessinger, and M.L. Gishizky. 1993. BCR-ABL-induced oncogenesis is mediated by direct interaction with the $\mathrm{SH} 2$ domain of the GRB-2 adaptor protein. Cell 75: 175-185.

Piao, X., R. Paulson, P. van der Geer, T. Pawson, and A. Bernstein. 1996. Oncogenic mutation in the Kit receptor tyrosine kinase al ters substrate specificity and induces degradation of the protein tyrosine phosphatase SHP-1. Proc. Natl. Acad. Sci. 93: 14665-14669.

Puil, L., J. Liu, G. Gish, G. M bamalu, D. Bowtell, P.G. Pelicci, R. Arlinghaus, and T. Pawson. 1994. Bcr-A bl oncoproteins bind directly to activators of the Ras signalling pathway. EMBO J. 13: 764-773.

Raitano, A.B., J.R. Hal pern, T.M. Hambuch, and C.L. Sawyers. 1995. The Bcr-Abl leukemia oncogene activates Jun kinase and requires Jun for transformation. Proc. Natl. Acad. Sci. 92: 11746-11750.

Rebay, I. and G.M. Rubin. 1995. Yan functions as a general inhibitor of differentiation and is negatively regulated by activation of the Ras1/MAPK pathway. Cell 81: 857-866.

Rechsteiner, M. and S.W. Rogers. 1996. PEST sequences and regulation by proteolysis. Trends Biochem. Sci. 21: 267-271.

Reuther, J.Y., G.W. Reuther, D. Cortez, A.M. Pendergast, and A.S. Baldwin Jr. 1998. A requirement for N F-kB activation in Bcr-Abl-mediated transformation. Genes \& Dev. 12: 968981.

Rosenberg, N. and O.N. Witte. 1988. The viral and cellular forms of the Abel son (abl) oncogene. Adv. Virus Res. 35: 3981.

Sal gia, R., B. Brunkhorst, E. Pisick, J.L. Li, S.H. Lo, L.B. Chen, and J.D. Griffin. 1995. Increased tyrosine phosphorylation of focal adhesion proteins in myeloid cell lines expressing p210BCR/ABL. Oncogene 11: 1149-1155.

Sal gia, R., J.L. Li, D.S. Ewaniuk, W. Pear, E. Pisick, S.A. Burky, T. Ernst, M. Sattler, L.B. Chen, and J.D. Griffin. 1997. BCR/ $A B L$ induces multiple abnormalities of cytoskeletal function. J. Clin. Invest. 100: 46-57.

Sanchez-Garcia, I. and G. Grutz. 1995. Tumorigenic activity of the BCR-ABL oncogenes is mediated by BCL2. Proc. Natl. Acad. Sci. 92: 5287-5291.

Sawyers, C.L., W. Callahan, and O.N. Witte. 1992. Dominant 


\section{Dai et al.}

negative MYC blocks transformation by $A B L$ oncogenes. Cell 70: 901-910.

-- - 1995. Genetic requirement for Ras in the transformation of fibroblasts and hematopoietic cells by the Bcr-Abl oncogene. J. Exp. Med. 181: 307-313.

Scheffner, M., B.A. Werness, J.M. Huibregtse, A.J. Levine, and P.M. Howley. 1990. The E6 oncoprotein encoded by human papillomavirus types 16 and 18 promotes the degradation of p53. Cell 63: 1129-1136.

Shi, Y., K. Alin, and S.P. Goff. 1995. Abl-interactor-1, a novel SH3 protein binding to the carboxy-terminal portion of the Abl protein, suppresses v-abl transforming activity. Genes \& Dev. 9: 2583-2597.

Skorski, T., P. Kanakaraj, M. Nieborowska-Skorska, M.Z. Ratajczak, S.C. Wen, G. Zon, A.M. Gewirtz, B. Perussia, and B. Cal abretta. 1995. Phosphatidylinositol-3 kinase activity is regulated by $B C R / A B L$ and is required for the growth of Philadel phia chromosome-positive cells. Blood 86: 726-736.

Skorski, T., A. Bellacosa, M. N ieborowska-Skorska, M. Majewski, R. Martinez, J.K. Choi, R. Trotta, P. Wlodarski, D. Perrotti, T.O. Chan, M.A. Wasik, P.N. Tsichlis, and B. Calabretta. 1997. Transformation of hematopoietic cells by BCR/ $A B L$ requires activation of a $\mathrm{PI}-3 \mathrm{k} / \mathrm{Akt}$-dependent pathway. EMBO J. 16: 6151-6161.

Skowyra, D., K.L. Craig, M. Tyers, S.J. Elledge, and J.W. Harper. 1997. F-box proteins are receptors that recruit phosphorylated substrates to the SCF ubiquitin-ligase complex. Cell 91: 209-219.

Tang, A.H., T.P. Neufeld, E. Kwan, and G.M. Rubin. 1997. PHYL acts to down-regulate TTK88, a transcriptional repressor of neuronal cell fates, by a SIN A-dependent mechanism. Cell 90: 459-467.

Treier, M., L.M. Staszewski, and D. Bohmann. 1994. Ubiquitindependent c-Jun degradation in vivo is mediated by the delta domain. Cell 78: 787-798.

Varshavsky, A. 1997. The ubiquitin system. Trends Biochem. Sci. 22: 383-387.

Verma, R., R.S. Annan, M.J. Huddleston, S.A. Carr, G. Reynard, and R.J. Deshaies. 1997. Phosphorylation of Siclp by G1 C dk required for its degradation and entry into $S$ phase. Science 278: 455-460.

Wada, H., S. Mizutani, J. N ishimura, Y. U suki, M. Kohsaki, M. Komai, H. Kaneko, S. Sakamoto, D. Delia, A. Kanamaru, and E. Kakishita. 1995. Establishment and molecular characterization of a novel leukemic cell line with Philadel phia chromosome expressing p230 BCR/ABL fusion protein. Cancer Res. 55: 3192-3196.

Wang, B., T. Mysliwiec, D. Krainc, R.A. Jensen, G. Sonoda, J.R. Testa, E.A. Golemis, and G.D. Kruh. 1996. Identification of ArgBP1, an Arg protein tyrosine kinase binding protein that is the human homologue of a CN S-specific Xenopus gene. Oncogene 12: 1921-1929. 


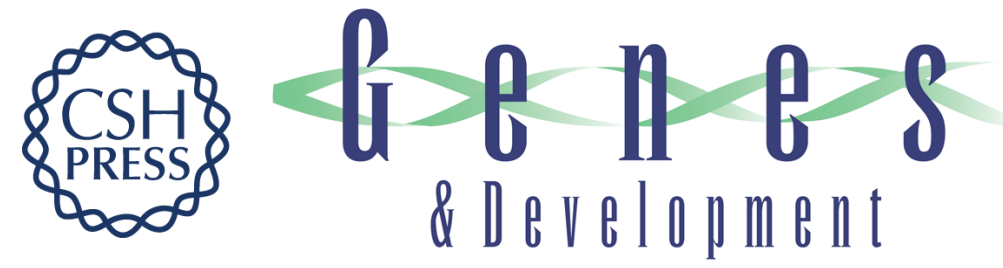

\title{
Oncogenic Abl and Src tyrosine kinases elicit the ubiquitin-dependent degradation of target proteins through a Ras-independent pathway
}

\author{
Zonghan Dai, Robert C. Quackenbush, Kevin D. Courtney, et al.
}

Genes Dev. 1998, 12:

Access the most recent version at doi:10.1101/gad.12.10.1415

References

This article cites 55 articles, 24 of which can be accessed free at:

http://genesdev.cshlp.org/content/12/10/1415.full.html\#ref-list-1

License

Email Alerting

Receive free email alerts when new articles cite this article - sign up in the box at the top

Service right corner of the article or click here.

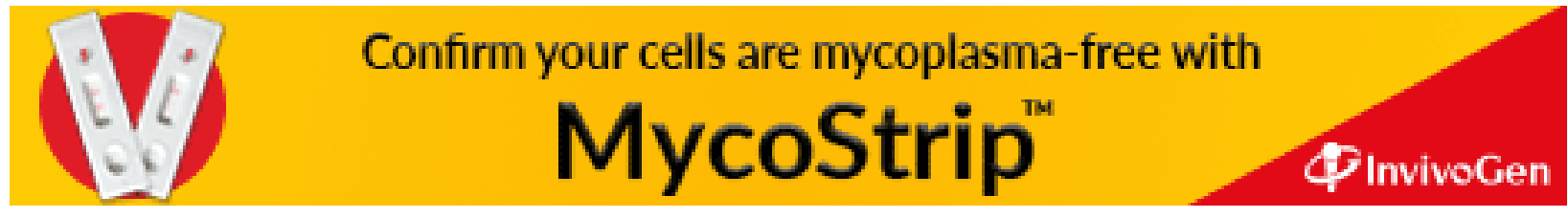

